\title{
Perbandingan Efektivitas Anestesi Spinal Menggunakan Bupivakain 0,5\% Hiperbarik Dosis 7,5 Mg dengan 5 Mg pada Seksio Sesarea
}

\author{
Muh. Zulkifli, Andi Salahuddin, Muh. Ramli Ahmad \\ Departemen Anestesiologi, Perawatan intensif, dan Manajemen Nyeri Fakultas Kedokteran Universitas Hasanuddin \\ Makassar
}

\begin{abstract}
Abstrak
Latar Belakang: Teknik anestesi yang efektif adalah tujuan utama dari teknik anestesi spinal, yang bertujuan meminimalkan efek samping pada ibu dan bayi baru lahir.

Tujuan: Membandingkan ketinggian blok, onset dan durasi, efek samping antara Bupivakain 0,5\% Hiperbarik dosis 7,5 Mg + Fentanyl $25 \mathrm{Mcg}$ dan dosis $5 \mathrm{Mg}+$ Fentanyl $25 \mathrm{Mcg}$ pada seksio sesarea.

Metode: Penelitian ini menggunakan pendekatan uji klinis acak tersamar ganda (Randomized double blind clinical trial). Sampel terdiri atas 2 kelompok yakni LD (Kelompok yang mendapatkan anestesi spinal bupivakain 0,5\% hiperbarik $5 \mathrm{mg}+$ fentanil $25 \mu \mathrm{g}$ ) dan CD (Kelompok yang mendapatkan anestesi spinal bupivakain 0,5\% hiperbarik 7,5 mg + fentanil $25 \mu \mathrm{g}$ ) dengan jumlah sampel masing-masing 20 orang. Data dianalisis menggunakan uji statistik Independen Sample T Test dengan tingkat kemaknaan $\alpha=0.05$.

Hasil: Ada perbedaan onset blok motorik $(p=0,004)$, durasi motorik $(p=0,000)$, durasi blok sensoris $(p=0,000)$ antara kelompok LD dan kelompok CD. Sedangkan durasi operasi $(p=0,769)$, selisih perubahan TD Sistole $(p>$ $0,05)$, selisih perubahan TD Diatole $(p>0,05)$, selisih perubahan nadi $(p>0,05)$, selisih perubahan MAP $(p>0,05)$, efek samping mual/muntah $(\mathrm{p}>0,05)$ dan rescue $(\mathrm{p}>0,05)$ menunjukkan tidak ada perbedaan.

Simpulan: Onset blok sensorik lebih lama, dan durasi blok sensoris dan motorik lebih singkat pada kelompok LD dibanding CD sehingga ada perbedaan efektifitas bupivakain antara kedua kelompok. Tidak perbedaan yang bermakna untuk efek samping dan perubahan hemodinamik pada kedua kelompok.
\end{abstract}

Kata kunci: bupivacain; durasi blok; nadi; onset blok; tekanan darah

\section{The Effectiveness of Spinal Anesthesia Using Bupivacaine 0.5\% Hyperbaric Dosage 7.5 Mg with 5 Mg in Caesarean Section Surgery}

\begin{abstract}
Background: Effective anesthesia techniques are the main goal of the spinal anesthesia technique, which aims to minimize side effects on the mother and newborn baby.

Objective: Comparing block height, onset and duration, side effects between Bupivacaine 0.5\% Hyperbaric dose $7.5 \mathrm{Mg}+$ Fentanyl $25 \mathrm{Mcg}$ and dose $5 \mathrm{Mg}+$ Fentanyl $25 \mathrm{Mcg}$ in cesarean section surgery.

Method: This study used a randomized double blind clinical trial approach. The sample consisted of 2 groups namely LD (group who received $0.5 \%$ hyperbaric bupivacaine $5 \mathrm{mg}+$ fentanyl $25 \mu \mathrm{g}$ anesthesia) and CD (group who received spinal anesthetic $0.5 \%$ hyperbaric bupivacaine $7.5 \mathrm{mg}+$ fentanyl $25 \mu \mathrm{g}$ ) with the number of samples was 20 people each. Data were analyzed using Independent Sample T Test statistic test with significance level $\alpha=0.05$. Results: There were differences in the motor block onset $(p=0.004)$, motor duration $(p=0,000)$, sensory block duration $(p=0,000)$ between the LD group and the CD group. While the duration of surgery $(p=0.769)$, the difference in TD Sistole changes $(p>0.05)$, the difference in changes in TD Diatole $(p>0.05)$, the difference in pulse change $(p>0.05)$, the difference in MAP changes $(p>0.05)$, side effects of nausea / vomiting $(p>0.05)$ and rescue $(\mathrm{p}>0.05)$ showed no difference.

Conclusion: Sensory block onset was longer, and sensory and motor block duration was shorter in the LD group than in CD so there was a difference in Bupivacaine effectiveness between the two groups. There were no significant differences in side effects and hemodynamic change in the two groups.
\end{abstract}

Key words: bupivacaine; block onset; block duration; blood pressure; pulse 


\section{Pendahuluan}

Anestesi regional merupakan faktor utama dalam upaya keselamatan pasien selama persalinan melalui seksio sesarea. Kebangkitan anestesi spinal sebagai teknik sederhana dan popular digunakan karena perkembangannya. Jarum spinal kecil dengan ujung pensil dan telah menjadi metode anestesi pilihan untuk operasi elektif dan untuk banyak kelahiran seksio sesarea darurat jika kateter epidural belum ada. Teknik anestesi yang efektif adalah tujuan utama dari teknik anestesi spinal, yang bertujuan meminimalkan efek samping pada ibu dan bayi baru lahir. ${ }^{1,2}$

Meskipun berbagai faktor mempengaruhi blok saraf sensorik pada anestesi spinal, dosis anestesi lokal adalah salah satu penentu utama keberhasilannya. Buku teks anestesi merekomendasikan bupivakain dengan dosis antara 12 dan $15 \mathrm{mg}$. Namun, penggunaan rentang dosis ini telah terkait dengan kejadian hipotensi yang mengakibatkan morbiditas ibu dan bayi baru lahir. Sejumlah penelitian telah mencari dosis bupivakain yang optimal, tetapi menghasilkan temuan berbeda dengan rentang dosis dari 5 hingga $20 \mathrm{mg}$. Penggunaan dosis yang lebih rendah bertujuan untuk menurunkan efek samping ibu (hipotensi, mual /muntah intraoperatif), mengurangi waktu untuk keluar dari unit perawatan post anestesi, dan meningkatkan kepuasan ibu. Namun, strategi semacam itu dapat membahayakan kecukupan anestesi, dan membutuhkan analgesia tambahan, dengan kemungkinan konsekuensi neonatal dan mungkin memerlukan konversi ke teknik anestesi umum, situasi yang dikenal sebagai faktor risiko untuk morbiditas dan mortalitas terkait anestesi terkait. ${ }^{3,4}$ Terdapat beberapa penelitian mengenai penggunaan obat anestesi lokal dosis rendah pada seksio sesarea. Penelitian tersebut menyimpulkan bahwa penggunaan bupivakain dosis rendah menunjukkan insidens hipotensi, mual, muntah yang lebih rendah, pengurangan kebutuhan ephedrin yang signifikan dan mengurangi durasi blok motorik. Penambahan opioid pada obat anestesi lokal intratekal telah dibuktikan memiliki efek analgesia yang saling menguatkan. Opioid intratekal meningkatkan efek analgesia dari dosis subterapeutik obat anestesi lokal sehingga memungkinkan untuk mencapai anestesi meskipun dengan dosis obat anestesi lokal yang tidak adekuat. Penelitian yang dilakukan terhadap 66 wanita hamil yang menjalani seksio sesarea dengan membandingkan bupivakain 8 $\mathrm{mg}$ dan $10 \mathrm{mg}$ dengan ajuvan morfin dan clonidin menunjukkan bahwa penambahan morfin dan clonidin terhadap bupivakain hiperbarik dosis rendah menghasilkan anestesi yang adekuat untuk seksio sesarea dan analgesia post operatif yang baik tanpa efek samping terhadap ibu dan bayi. ${ }^{5,6}$ Penelitian-penelitian yang menggunakan obat anestesi lokal dosis rendah, dalam hal ini bupivakain hiperbarik $0,5 \%$ untuk prosedur seksio sesarea melatar belakangi dilakukannya penelitian ini. Berkurangnya kejadian gangguan hemodinamik pada pasien yang diberikan bupivakain dosis rendah dengan durasi analgesia yang mencukupi kebutuhan prosedur ini diharapkan dapat mengurangi morbiditas dan mortalitas sehubungan dengan teknik anestesi spinal. Ulasan narasi dengan tinjauan terbaru telah membahas kontroversi spinal bupivakain dalam dosis rendah (low dose). Oleh karena itu kami melakukan peninjauan sistematis literatur tentang kemanjuran dan efek samping dari bupivakain spinal pada low dose (LD) dibandingkan dengan conventional dose (CD) untuk seksio sesarea elektif.

\section{Metode}

Penelitian ini menggunakan uji klinis acak terkontrol secara random tersamar ganda (Randomized double blind controlled trial) dengan tujuan untuk membandingkan ketinggian blok, onset dan durasi, efek samping dengan penilaian skala bromage antara anestesi spinal bupivakain $0,5 \%$ hiperbarik $7,5 \mathrm{mg}+$ fentanyl $25 \mathrm{mcg}$ dibandingkan bupivakain $0,5 \% 5 \mathrm{mg}+$ fentanyl $25 \mathrm{mcg}$. Kriteria inklusi: pasien yang menjalani seksio sesarea elektif dan emergensi, setuju dilakukan teknik anestesi spinalstatus fisik ASA I-II, usia 20-45 tahun, Indeks Massa Tubuh (IMT) $18,50-24,99 \mathrm{~kg} / \mathrm{m}^{2}$. Kriteria ekslusi: pasien tidak kooperatif, kontraindikasi dilakukan anestesi spinal, preeklampsi/ eklampsi berat, alergi terhadap obat lokal anestesi. Kriteria 
drop out: prosedur operasi memanjang $>3$ jam, konversi ke anestesi umum selama seksio sesarea. Penelitian ini dilakukan di RSUP DR. Wahidin Sudirohusodo Makassar dan jejaringnya dan dimulai pada bulan oktober sampai desember 2019. Penelitian ini dibagi menjadi dua kelompok yaitu kelompok Low Dose (LD) Bupivakain hiperbarik $0,5 \% 5 \mathrm{mg}$ dengan fentanyl $25 \mathrm{mcg}$ ditambahkan $\mathrm{NaCl}$ 0,9\% (total volume $2 \mathrm{ml}$ ). Pada kelompok Conventional Dose (CD) Bupivakain hiperbarik 0,5\% 7,5 mg dengan fentanil $25 \mathrm{mcg}$ (total volume $2 \mathrm{ml}$ ) pada seksio sesarea dengan anestesi spinal. Jumlah sampel total 30 pasien, masing-masing kelompok 15 pasien.

Setelah pasien tiba di ruang tunggu kamar, pasien diperiksa ulang terhadap identitas, diagnosis, rencana tindakan pembiusan dan akses infus (pastikan telah terpasang infus dengan kateter intravena $18 \mathrm{G}$, threeway, dan aliran infus lancar). Sebelum pasien memasuki kamar operasi, disiapkan mesin anestesi yang dihubungkan dengan sumber oksigen. Juga disiapkan set alat intubasi, endotrakheal tube (ETT), dan obat-obat emergensi injeksi seperti epinefrin, sulfas atrofin, efedrin, dan deksametason. Kemudian pasien dibawa memasuki kamar operasi, dipasang alat pemantau (monitoring) pada tubuh pasien dan dicatat data mengenai tekanan darah, laju nadi, dan laju nafas. Kemudian pasien pada kedua kelompok diberikan preloading cairan $500 \mathrm{cc}$ Ringer Laktat secara intravena.

Anestesi spinal dilakukan dengan posisi lateral dekubitus menggunakan jarum spinal ukuran 25G. Segera setelah injeksi spinal, pasien di posisikan supine dengan bantal di bawah kepala dan diberikan $\mathrm{O}_{2}$ lewat nasal kanul 2-3 L/min. Akhir injeksi anestesi lokal adalah waktu untuk mengukur onset blok sensorik dan blok motorik, blok sensorik dinilai menggunakan test pin prick sesuai dermatoanalgesia dan blok motorik di nilai dengan menggunakan skala bromage. Onset blok sensorik diobservasi setiap 1 menit dimulai dari selesai injeksi obat anestei lokal sampai blok sensorik maksimal dicapai. Onset blok motorik diobservasi setiap 1 menit mulai dari selesai injeksi obat anestesi lokal hingga dicapai skala bromage 3 .
Pada kelompok Low Dose (LD) diberikan kombinasi anestetik lokal Bupivakain hiperbarik 0,5\% $5 \mathrm{mg}$ dengan fentanyl $25 \mathrm{mcg}$ ditambahkan $\mathrm{NaCl}$ 0,9 \% (total volume $2 \mathrm{ml}$ ). Pada kelompok Conventional Dose (CD) diberikan kombinasi anestetik lokal Bupivakain hiperbarik 0,5\% 7,5 mg dengan fentanyl $25 \mathrm{mcg}$ (total volume $2 \mathrm{ml}$ ). Operasi dimulai setelah dilakukan blok sensorik setinggi dermatom torakal 6 dengan tes pinprick, dan blok motorik maksimal yang dinilai dengan skala Bromage. Kemudian tekanan darah dan laju jantung diukur setiap 3 menit sampai 30 menit (T1 - T10) setelah dilakukan anestesi spinal. Tekanan darah diukur dengan metode non invasif dan laju jantung dicatat sesuai dengan electrocardiogram pada monitor. Bila terjadi hipotensi (tekanan darah $<20 \%$ dari tekanan darah), diberikan bolus cairan RL 2 mL/kg. Maksimal diberikan tiga kali bolus. Bila suplementasi cairan intravena gagal untuk mengatasi hipotensi, diberikan efedrin 5-10 mg bolus. Bila terjadi bradikardi (laju jantung $<50 \mathrm{kali} / \mathrm{menit}$ ) diatasi dengan diberikan sulfat atropin $0,5 \mathrm{mg}$ dengan dosis maksimum $2 \mathrm{mg}$. Pasien juga dimonitor untuk semua efek samping selama pembedahan dicatat kejadian blok motorik, hipotensi, bradikardi, pruritus, menggigil, dan depresi nafas. Tekanan darah, nadi, saturasi oksigen, kebutuhan akan analgetik tambahan, dan kejadian mual muntah dipantau selama operasi berjalan, setelah operasi hingga pasien di observasi di Post Anesthetic Care (PACU) dan dipindahkan ke ruangan.

Sebelum penelitian dilaksanakan, peneliti meminta keterangan kelayakan etik (ethical clearance) dari komisi Etik Penelitian Biomedis pada manusia Fakultas Kedokteran Universitas Hasanuddin. Semua keluarga penderita yang memenuhi kriteria inklusi diberi penjelasan secara lisan dan menandatangani lembar persetujuan untuk ikut dalam penelitian secara sukarela. Bila karena suatu alasan penderita/keluarga penderita berhak mengundurkan diri dari penelitian ini. Setelah data yang diperlukan terkumpul, kemudian data tersebut diperiksa kembali tentang kelengkapannya sebelum ditabulasi dan diolah. Data dikumpulkan ke dalam master tabel dengan menggunakan software Microsoft Office Excel 2010. Setelah data semua lengkap kemudian 
data diolah dengan menggunakan SPSS 20. Data numerik dari hasil akan ditampilkan dalam mean dan SD (Standar Deviasi). Data demografi untuk uji proporsi menggunakan uji Chi Square, sementara untuk data interval digunakan uji Kolmogorov Smirnov untuk uji kenormalan. Jika normal menggunakan uji $\mathrm{T}$ independent, jika tidak normal menggunakan uji Mann Whitney. Interval kepercayaan $95 \%$ dengan nilai $\mathrm{p}<0,05$, dianggap bermakna secara signifikan.

\section{Hasil}

Hasil analisis pada tabel 1 menunjukkan bahwa tidak ditemukan perbedaan umur yang bermakna antara kedua kelompok $(\mathrm{p} \geq 0,05)$. Mean \pm SD

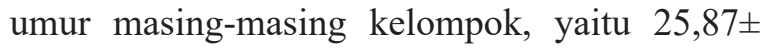
5,61 tahun untuk kelompok LD dan 26,80土6,48 tahun untuk Kelompok CD. Begitupula untuk BMI, tidak ditemukan perbedaan yang bermakna ( $\mathrm{p} \geq 0,05)$ antara kedua kelompok. Mean $\pm \mathrm{SD}$ BMI $26,38 \pm 3,22 \mathrm{~kg} / \mathrm{m} 2$ untuk kelompok LD dan $25,83 \pm 3,05 \mathrm{~kg} / \mathrm{m} 2$ untuk Kelompok CD. Artinya, kedua kelompok dapat dianggap homogen berdasarkan karakteristik umur dan BMI.

Tabel 1. Distribusi sampel Berdasarkan Umur dan IMT pada Kedua Kelompok

\begin{tabular}{|c|c|c|c|}
\hline \multirow[t]{2}{*}{ Karakteristik } & $\begin{array}{l}\text { Kelompok } \\
\text { LD (n=15) }\end{array}$ & $\begin{array}{l}\text { Kelompok } \\
\text { CD }(n=15)\end{array}$ & \multirow[t]{2}{*}{$\mathbf{p}$} \\
\hline & $\begin{array}{l}\text { Mean } \pm \\
\text { SD }\end{array}$ & $\begin{array}{l}\text { Mean } \pm \\
\text { SD }\end{array}$ & \\
\hline Umur (tahun) & $\begin{array}{l}25,87 \pm \\
5,61\end{array}$ & $26,80 \pm 6,48$ & 0,677 \\
\hline BMI (kg/m2) & $26,38 \pm 3,22$ & $\begin{array}{l}25,83 \\
\pm 3,05\end{array}$ & 0,638 \\
\hline
\end{tabular}

Distribusi sampel berdasar umur dan IMT diuji dengan Uji Independent $\mathrm{T}$ Test, ${ }^{*} \mathrm{p}<0,05$ dinyatakan bermakna.

Onset dan Durasi Blok Sensoris dan Blok Motorik Hasil analisis pada tabel 2 menunjukkan perbedaan tidak bermakna onset blok sensoris antara kedua kelompok $(\mathrm{p} \geq 0,05)$. Mean \pm SD onset sensoris masing-masing kelompok secara statistik, yaitu 3,20 $\pm 1,61$ untuk kelompok LD dan 2,73 $\pm 0,70$ untuk Kelompok CD. Adapun untuk onset blok sensoris ditemukan perbedaan yang bermakna
( $\mathrm{p}<0,05)$ antara kedua kelompok. Mean $\pm \mathrm{SD}$ onset motorik 6,27 $\pm 2,28$ untuk kelompok LD dan 4,53 $\pm 1,35$ untuk Kelompok CD. Artinya, kelompok LD secara statistik berbeda dengan kelompok $\mathrm{CD}$ dalam hal onset motorik. Pada tabel 2 juga ditemukan perbedaan bermakna durasi blok sensoris antara kedua kelompok ( $\mathrm{p}<$ $0,05)$. Mean \pm SD durasi blok sensoris masing-

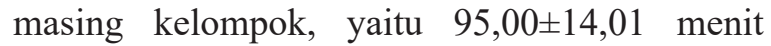
untuk kelompok LD dan 123,67 $\pm 10,60$ menit untuk Kelompok CD. Adapun untuk durasi blok motirik juga ditemukan perbedaan yang bermakna $(\mathrm{p}<0,05)$ antara kedua kelompok. Mean \pm SD durasi blok motorik $170,67 \pm 20,86$ menit untuk kelompok LD dan 245,60 $\pm 29,78$ untuk Kelompok CD. Sedangkan untuk waktu operasi ditemukan perbedaan tidak bermakna durasi operasi yang bermakna antara kedua kelompok $(\mathrm{p} \geq 0,05)$. Mean $\pm \mathrm{SD}$ durasi operasi masingmasing kelompok, yaitu 67,60 10,76 menit untuk kelompok LD dan 63,33 $\pm 10,63$ menit untuk Kelompok CD. Artinya, kelompok LD secara statistik berbeda dengan kelompok CD dalam hal durasi blok sensoris dan durasi blok motorik, namun tidak berbeda dalam hal durasi operasi. Perbandingan onset dan durasi blok sensoris dan motorik diuji dengan Uji Independent T Test, * $\mathrm{p}<0,05$ dinyatakan bermakna.

\section{Perubahan Tekanan Darah}

Hasil analisis pada tabel 3 menunjukkan perbedaan bermakna antara mean selisih tekanan sistole antara kelompok LD dan CD $(\mathrm{p} \geq 0,05)$ pada mean TDS0-TDS1, TDS0-TDS2, TDS0TDS3, TDS0-TDS4, TDS0-TDS5, TDS0-TDS6, TDS0-TDS7, TDS0-TDS8, TDS0-TDS9, dan TDS0-TDS10. Perbandingan mean selisih tekanan sistole antara kelompok LD dan CD diuji menggunakan uji independen $\mathrm{t}$ test, dimana $\mathrm{p}<$ 0,05 dinyatakan bermakna. Perbandingan selisih tekanan darah sistole antara kedua kelompok diuji dengan Uji Independent $\mathrm{T}$ Test, ${ }^{*} \mathrm{p}<0,05$ dinyatakan bermakna.

\section{Efek Samping Mual/ Muntah}

Hasil analisis pada tabel 4 ditemukan perbedaan tidak bermakna efek samping mual antara kedua kelompok $(\mathrm{p} \geq 0,05)$. Pada Kelompok LD dan CD semuanya tidak mengalami mual (100,0\%). 
Tabel 2. Perbandingan Onset dan Durasi Blok Sensoris dan Motorik antara Kelompok LD dan Kelompok CD

\begin{tabular}{|c|c|c|c|}
\hline & Kelompok LD $(\mathrm{n}=15)$ & Kelompok CD $(\mathrm{n}=15)$ & \multirow[t]{2}{*}{$\mathrm{p}$} \\
\hline & Mean $\pm \mathrm{SD}$ & Mean $\pm \mathrm{SD}$ & \\
\hline \multicolumn{4}{|l|}{ Onset } \\
\hline Blok Sensoris & $3,20 \pm 1,61$ & $2,73 \pm 0,70$ & 0,317 \\
\hline Blok Motorik & $6,27 \pm 2,28$ & $4,53 \pm 1,35$ & 0,019 \\
\hline \multicolumn{4}{|l|}{ Durasi } \\
\hline Blok Sensoris & $95,00 \pm 14,01$ & $123,67 \pm 10,60$ & 0,000 \\
\hline Blok Motorik & $170,67 \pm 20,86$ & $245,60 \pm 29,78$ & 0,000 \\
\hline Waktu Operasi & $67,60 \pm 10,76$ & $63,33 \pm 10,63$ & 0,284 \\
\hline
\end{tabular}

Tabel 3. Perbandingan Selisih Sistole antara Kelompok LD dan Kelompok CD

\begin{tabular}{|c|c|c|c|}
\hline \multirow[t]{2}{*}{ Selisih Sistole } & Kelompok LD (n=15) & Kelompok CD $(\mathrm{n}=15)$ & \multirow[t]{2}{*}{$\mathrm{P}$} \\
\hline & Mean $\pm \mathrm{SD}$ & Mean $\pm \mathrm{SD}$ & \\
\hline TDS0-TDS1 & $3,27 \pm 12,99$ & $10,40 \pm 11,01$ & 0,116 \\
\hline TDS0-TDS2 & $3,27 \pm 12,99$ & $10,40 \pm 11,01$ & 0,116 \\
\hline TDS0-TDS3 & $8,13 \pm 14,47$ & $9,67 \pm 11,84$ & 0,753 \\
\hline TDS0-TDS4 & $9,13 \pm 14,10$ & $14,80 \pm 9,26$ & 0,204 \\
\hline TDS0-TDS5 & $10,40 \pm 15,99$ & $17,47 \pm 10,45$ & 0,163 \\
\hline TDS0-TDS6 & $11,53 \pm 13,83$ & $16,13 \pm 9,89$ & 0,304 \\
\hline TDS0-TDS7 & $9,20 \pm 15,20$ & $15,67 \pm 13,35$ & 0,226 \\
\hline TDS0-TDS8 & $8,07 \pm 16,75$ & $12,47 \pm 14,28$ & 0,445 \\
\hline TDS0-TDS9 & $8,27 \pm 14,49$ & $13,07 \pm 13,92$ & 0,363 \\
\hline TDS0-TDS10 & $10,60 \pm 14,88$ & $11,13 \pm 18,43$ & 0,931 \\
\hline
\end{tabular}

Tabel 4. Perbandingan Efek samping Mual/ Muntah pada Kedua Kelompok

\begin{tabular}{llllll}
\hline Efek Samping & \multicolumn{3}{l}{ Kelompok LD $(\mathrm{n}=15)$} & \multicolumn{3}{l}{ Kelompok CD $(\mathrm{n}=15)$} & $\mathrm{P}$ \\
\cline { 2 - 5 } & $\mathrm{n}$ & $\%$ & $\mathrm{n}$ & $\%$ & \\
\hline Mual & 15 & 100 & 15 & 100 & 1,000 \\
Negatif & 0 & 00 & 0 & 0 & \\
Positif & 15 & 100 & 15 & 100 & 1,000 \\
Muntah & 0 & 00 & 0 & 0 & \\
$\begin{array}{l}\text { Negatif } \\
\text { Positif }\end{array}$ & \multicolumn{5}{l}{} \\
$\begin{array}{l}\text { Perbandingan efek samping mual/ muntah diuji dengan Uji Eksak Fisher, } \mathrm{P}<0,05 \\
\text { dinyatakan bermakna. }\end{array}$
\end{tabular}


Demikian pula dengan efek samping muntah ditemukan tidak ada perbedaan yang bermakna efek samping muntah antara kedua kelompok $(\mathrm{p} \geq 0,05)$. Pada Kelompok LD dan CD semuanya tidak mengalami muntah $(100,0 \%)$.

\section{Rescue Efedrin}

Hasil analisis pada tabel 5 menunjukkan bahwa ditemukan tidak ada perbedaan yang bermakna kejadian rescue efedrin antara kedua kelompok $(\mathrm{p} \geq 0,05)$. Pada Kelompok LD, kejadian rescue efedrinn yaitu sebanyak 2 orang $(13,3 \%)$ sementara pada Kelompok CD terdapat kejadian rescue efedrin sebanyak 2 orang $(13,3 \%)$.

\section{Pembahasan}

Karakteristik sampel penelitian kedua kelompok meliputiumur,BMI.Hasilpenelitianmenunjukkan perbedaan tidak bermakna umur, BMI antara kedua kelompok $(\mathrm{p} \geq 0,05)$. Untuk variabelvariabel karakteristik pasien tersebut, ditemukan perbedaan tidak bermakna secara statistik antara kedua kelompok. Hal ini menunjukkan adanya homogenitas kedua kelompok sehingga layak untuk dibandingkan. Hasil penelitian ini ditemukan perbedaan tidak bermakna onset blok sensoris antara kedua kelompok ( $\mathrm{p} \geq 0,05)$. Mean onset sensoris masing-masing kelompok, yaitu 3,20 menit untuk kelompok LD dan 2,73 menit untuk Kelompok CD. Adapun untuk onset blok motorik ditemukan ada perbedaan yang bermakna $(\mathrm{p}<0,05)$ antara kedua kelompok. Mean onset motorik 6,27 menit untuk kelompok LD dan 4,53 menit untuk Kelompok CD.

Pada penelitian lainnya onset blok sensorik pada kelompok bupivakain hiperbarik $0,5 \% 5$ mg adjuvant morfin $100 \mu \mathrm{g}$ dan klonidin $45 \mu \mathrm{g}$ rerata 105 detik dan pada kelompok kelompok bupivakain hiperbarik $0,5 \% \quad 10 \mathrm{mg}$ adjuvant morfin $100 \mu \mathrm{g}$ dan klonidin $45 \mu \mathrm{g}$ adalah 63 detik, dengan nilai $\mathrm{p}=0,000 .{ }^{7} \mathrm{Hal}$ ini sesuai dengan penelitian yang membandingkan bupivakain 5 mg dengan ajuvan fentanyl $25 \mu \mathrm{g}$ dan bupivakain $10 \mathrm{mg}$ tanpa ajuvan. ${ }^{8}$ Pada penelitian lainnya yang membandingkan bupivakain $7,5 \mathrm{mg}$ dan bupivakain $10 \mathrm{mg}$ dengan ajuvan fentanyl $20 \mu \mathrm{g}$ tidak didapatkan perbedaan yang signifikan, tetapi hasil yang didapatkan serupa, yaitu onset blok kelompok bupivakain $10 \mathrm{mg}$ lebih cepat daripada kelompok bupivakain 7,5 mg. ${ }^{9}$ Satu penelitian menyatakan bahwa onset blok sensorik lebih cepat dengan semakin bertambahnya dosis. ${ }^{10} \mathrm{Hal}$ ini sejalan dengan teori di mana salah satu faktor yang mempengaruhi ketinggian blok adalah volume (dosis) obat. Semakin besar volumenya, semakin tinggi blok yang dicapai. ${ }^{11,12}$

Hasil penelitian ini ditemukan perbedaan bermakna durasi blok sensoris antara kedua kelompok $(\mathrm{p}<0,05)$. Mean durasi blok sensoris masing-masing kelompok, yaitu 95,00 menit untuk kelompok LD dan 123,67 menit untuk Kelompok CD. Adapun untuk durasi blok motorik juga ditemukan ada perbedaan yang bermakna ( $\mathrm{p}<$ $0,05)$ antara kedua kelompok. Mean durasi blok motorik 170,67 menit untuk kelompok LD dan 245,60 menit untuk Kelompok CD. Sedangkan untuk waktu operasi ditemukan perbedaan tidak bermakna durasi operasi antara kedua kelompok ( $\mathrm{p} \geq 0,05)$. Mean durasi operasi masing-masing kelompok, yaitu 67,60 menit untuk kelompok LD dan 63,33 menit untuk kelompok CD. Artinya, kelompok LD secara statistik berbeda dengan kelompok $\mathrm{CD}$ dalam hal durasi blok sensoris dan durasi blok motorik, namun tidak berbeda dalam hal durasi operasi. Pada penelitian lainnya durasi blok motorik pada kelompok bupivakain hiperbarik $0,5 \% 5 \mathrm{mg}$ adjuvant morfin $100 \mu \mathrm{g}$ dan klonidin $45 \mu \mathrm{g}$ rerata 146 menit dan pada kelompok kelompok bupivakain hiperbarik 0,5\% $10 \mathrm{mg}$ adjuvant morfin $100 \mu \mathrm{g}$ dan klonidin $45 \mu \mathrm{g}$ adalah 199 menit, dengan nilai $\mathrm{p}=0,000{ }^{7}$

Durasi obat anestesi lokal dapat dipengaruhi oleh beberapa faktor, meliputi dosis, semakin tinggi dosis yang digunakan maka durasi blok anestesi akan semakin lama. Farmakokinetik obat anestesi lokal, meliputi: ikatan dengan protein plasma (obat dengan ikatan protein yang lebih tinggi memiliki durasi blok yang lebih lama misalnya bupivakain), metabolisme obat, golongan ester di metabolise oleh enzim pseudocholinesterase dan amida di metabolism di hepar oleh enzim mikrosomal. Ester mempunyai durasi yang lebih singkat sedangkan amida memiliki durasi yang lebih lama. Bupivakain merupakan golongan 
amida. Penambahan obat-obat vasokonstriktor, vasokonstriktor dapat menurunkan absorbsi sistemik dari obat-obat anestesi lokal yang pada akhirnya dapat memperpanjang durasi blok..$^{11,12}$

Hasil penelitian ini ditemukan perbedaan tidak bermakna antara mean selisih tekanan sistole antara kelompok $\mathrm{LD}$ dan $\mathrm{CD}(\mathrm{p} \geq 0,05)$ pada mean TDS0-TDS1, TDS0-TDS2, TDS0-TDS3, TDS0TDS4, TDS0-TDS5, TDS0-TDS6, TDS0-TDS7, TDS0-TDS8, TDS0-TDS9, dan TDS0-TDS10. Selain itu, pada penelitian ini bahwa ditemukan perbedaan yang tidak bermakna antara mean selisih tekanan diastole antara kelompok LD dan CD ( $\mathrm{p} \geq 0,05)$ pada mean TDD0-TDD1, TDD0TDD2, TDD0-TDD3，TDD0-TDD4， TDD0TDD5, TDD0-TDD6, TDD0-TDD7, TDD0TDD8, TDD0-TDD9, dan TDD0-TDD10.

Berbeda pada penelitian lainnya yang membandingkan bupivakain hiperbarik $8 \mathrm{mg}$ dengan bupivakain hiperbarik $12 \mathrm{mg}$. Pada penelitian tersebut ditunjukkan bahwa dengan dosis $8 \mathrm{mg}$ kejadian hipotensi lebih rendah secara signifikan. ${ }^{9}$ Apabila dengan dosis $8 \mathrm{mg}$ kejadian hipotensi lebih rendah, tentunya dengan dosis yang lebih rendah kejadian hipotensi juga akan semakin berkurang. Hasil penelitian ini ditemukan perbedaan tidak bermakna efek samping mual antara kedua kelompok ( $\mathrm{p} \geq$ 0,05). Pada Kelompok LD dan CD semuanya tidak mengalami mual (100,0\%). Demikian pula dengan efek samping muntah ditemukan perbedaan tidak bermakna antara kedua kelompok $(\mathrm{p} \geq 0,05)$. Pada Kelompok LD dan CD semuanya tidak mengalami muntah (100,0\%). Pada penelitian lainnya kejadian mual dan muntah lebih tinggi pada bupivakain hiperbarik 0,5\% 10 mg dengan adjuvant dibandingkan bupivakain $5 \mathrm{mg}$ dengan adjuvant walaupun berbeda tidak bermakna antara kedua kelompok. ${ }^{7,13}$ Kejadian mual dan muntah lebih rendah bahkan tidak ditemukan pada kelompok bupivakain $5 \mathrm{mg}$. Hal ini kemungkinan disebabkan oleh rendahnya kejadian hipotensi yang menginduksi mual dan muntah. Obat anestesi lokal yang diinjeksikan intratekal tidak hanya memblok saraf nyeri tetapi juga menyebabkan vasodilatasi dengan mengenai saraf simpatis. Karena menginduksi simpatolisis, fluktuasi tekanan darah, dalam hal ini hipotensi yang signifikan, dapat terjadi. Selain itu, peningkatan tonus vagal menyebabkan bradikardia yang seringkali disertai mual dan muntah. ${ }^{14}$ Hasilpenelitian iniditemukan perbedaan tidak bermakna efek samping mual antara kedua kelompok $(\mathrm{p} \geq 0,05)$. Pada Kelompok LD dan CD semuanya tidak mengalami mual $(100,0 \%)$. Demikian pula dengan efek samping muntah ditemukan tidak ada perbedaan yang bermakna efek samping muntah antara kedua kelompok ( $\mathrm{p} \geq$ 0,05). Pada Kelompok LD dan CD semuanya tidak mengalami muntah $(100,0 \%)$. Kejadian mual/ muntah diuji menggunakan uji Eksak Fisher, dimana $p<0,05$ dinyatakan perbedaan bermakna. Pada penelitian lainnya kejadian mual dan muntah lebih tinggi pada bupivakain hiperbarik $0,5 \% 10$ mg dengan adjuvant dibandingkan bupivakain $5 \mathrm{mg}$ dengan adjuvant walaupun tidak berbeda signifikan antara kedua kelompok. $^{7}$ Kejadian mual dan muntah lebih rendah bahkan tidak ditemukan pada kelompok bupivakain $5 \mathrm{mg}$. Hal ini kemungkinan disebabkan oleh rendahnya kejadian hipotensi yang menginduksi mual dan muntah. Obat anestesi lokal yang diinjeksikan intratekal tidak hanya memblok saraf nyeri tetapi juga menyebabkan vasodilatasi dengan mengenai saraf simpatis. Karena menginduksi simpatolisis, fluktuasi tekanan darah, dalam hal ini hipotensi yang signifikan, dapat terjadi. Selain itu, peningkatan tonus vagal menyebabkan bradikardia yang seringkali disertai mual dan muntah. ${ }^{14}$

\section{Simpulan}

Onset blok sensorik lebih lama, dan durasi blok sensoris dan motoris lebih cepat pada kelompok LD dibanding CD sehingga ada perbedaan efektivitas anestesi spinal menggunakan bupivakain $0,5 \%$ hiperbarik dosis 7,5 $\mathrm{mg}+$ fentanyl $25 \mathrm{mcg}$ dengan bupivakain $0,5 \%$ hiperbarik dosis $5 \mathrm{mg}+$ fentanyl $25 \mathrm{mcg}$ pada pasien operasi seksio sesarea. Perbedaan tidak bermakna pada efek samping dan perubahan hemodinamik untuk kedua kelompok. Saran dapat dilakukan penelitian lebih lanjut mengenai teknik anestesi spinal dosis rendah yang digunakan pada jenis pembedahan lain dan membandingkan beberapa ajuvan berbeda. 


\section{Daftar Pustaka}

1. Mostafa, Anis, Mahmoud, Mohamed. Clinical comparative study of the effect oh intravenous ondansetron and granisetron on hemodynamic changes, shivering, and motor and sensory blockade induce by spinal anesthesia in women undergoing cesarean section. N Y Sci J. 2017; ;10(6):7-16.

2. Arzola C, Wieczorek PM. Efficacy of lowdose bupivacaine in spinal anaesthesia for Caesarean delivery: Systematic review and meta-analysis. Br J Anaesth [Internet]. 2011;107(3):308-18.

3. Meirowitz N, Katz A, Danzer B, Siegenfeld $\mathrm{R}$. Can the passive leg raise test predict spinal hypotension during cesarean delivery? An observational pilot study. Int J Obstet Anesth. 2012;21(4):324-8.

4. Hoyt MR, Pages EM. Anesthesia for Labor and Delivery [Internet]. Tenth Edition. Fanaroff and Martin's Neonatal-Perinatal Medicine, 2-Volume Set. Elsevier Inc.; 2015, 374-90.

5. Mylonas I, Friese K. Indications for and Risks of Elective Cesarean Section. Deutsch Ärztebl Int. 2015;112(29):489-95.

6. Eng HC, Ghosh SM, Chin KJ. Practical use of local anesthetics in regional anesthesia. Curr Opin Anaesthesiol. 2014;27(4):382-7.

7. Adyputra I. Perbandingan Pemberian Bupivakain hiperbarik $0,5 \% 5 \mathrm{Mg}$ dan 10 $\mathrm{Mg}$ terhadap kadar kortisol dan efektivitas anestesi spinal pada pembedahan seksio caesarea. Departemen Anestesi dan Terapi Intensif Fakultas Kedokteran Universitas Hasanuddin. 2019.

8. Woolf CJ, Max MB. Mechanism based pain diagnosis. Anesthesiology. 2001;95:241-9.

9. Venkata HG, Pasupuleti S, Pabba UG, Porika S, Talari G. A randomized controlled prospective study comparing a low dose bupivacaine and fentanyl mixture to a conventional dose of hyperbaric bupivacaine for Cesarean section. Saudi J Anesth. $2015 ; 9(2): 122-7$.

10. Roofthooft E, Velde M. Low dose spinal anaesthesia for Caesarean section to prevent spinal-induced hypotension. Curr Opin Anaesth. 2008;21(1):259-62.

11. Yadav A. Short textbook of anaesthesia, 2nd Ed. New Delhi: Academa Publishers; 2004, $16-27$.

12. Wong CA. Technique of Neuraxial Anesthesia. New York: McGraw-Hill; 2007, 229-46, 27-74.

13. Ben-David B, Miller G, Gavriel R, Gurevith A. Low-dose bupivacaine-fentanyl spinal anesthesia for Cesarean delivery. Reg Anesth Pain Med. 2000;25(3):235-9.

14. Jelting $Y$, Klein C, Harlander T, Eberhart L, Roewer N, Kranke P. Preventing nausea and vomiting in women undergoing regional anesthesia for cesarean section: challenge and solutions. Loc Reg Anesth. 2017;10: 83-90. 